\title{
Die figuur van Van Broekhuizen, uit die geskiedenis van die Gemeente Pretoria
}

\author{
AD Pont
}

\section{INLEIDENDE OPMERKINGS}

In die $\mathbf{1 2 5}$ jaar wat die Gemeente Pretoria bestaan, het uit die aard van die saak baie predikante, elk met sy eie bekwaamhede, in die Gemeente geleef en gewerk. Dit is nogal opmerklik, as gelet word op die lang ry van predikante, hoe hierdie manne nie net op kerklike vlak nie, maar óók op die lewensterreine van die volkslewe, die kultuur en die politiek, belangrike bydraes gemaak het. Dit het wel meegebring dat heelwat van Pretoria se predikante sogenaamde "omstrede figure" was en hoewel daar rondom hulle persone en werk nogal stof opgewaai het, is dit vandag duidelik dat dit dikwels die koers- en rigtingvaste predikante is wat nie maar net inval by die aanvaarde opvattings van die oomblik nie, wat die "omstrede figure" geword het.

In 'n sekere sin, as op die geskiedenis gelet word, is dit ook verstaanbaar wáárom daar moontlikhede vir die predikante was om as "omstrede" beskryf te word. Die Gemeente Pretoria, gestig in 1855, het nie alleen die wordingsjare van die ou Republiek beleef nie, maar ook die twee Engelse oorloë van 1880-1881 en 1899-1902, en verder die Rebellie van 1914, die worstelstryd van die Afrikanervolk om na 1902 'n eie staanplek in sy verowerde vaderland te behou en om kerklik, kultureel en polities sy geestes-eiendomlike te bewaar. Daarby het die swak-beplande kerkverenigingspoging van 1885 ook vir baie jare 'n blywende letsel op die Gemeente gelaat. Dit was dan ook so dat in hierdie Gemeente verskillende strominge en opvattings gehuisves was wat weer interne spanninge en woelinge na vore gebring het en geen wonder dat van die predikante, wat hier die leiding moes gee, dikwels in die middelpunt van oplaaiende stryd gestaan het.

Een van die interessante figure wat hier predikant was, was dr HD van Broekhuizen, 1871-1953, wat van 1917-1925 predikant van die Gemeente was. Sy koms, as predikant na die Gemeente Pretoria, het soveel probleme veroorsaak dat selfs ' $n$ buitengewone Algemene Kerkvergadering gehou moes word. Dit alléén al wys dat hier 'n buitengewone situasie ontstaan het. 


\section{BIOGRAFIESE SKETS}

Herman Dirk van Broekhuizen is op 17-6-1871 te Rüssen in Overijssel ( $\mathrm{Ndl}$ ) gebore as die seun van ds Herman van Broekhuizen en Johanna van Beest van Andel, 'n Vrystaatse NG-pastoriepaar wat tydelik in Nederland gewoon en gewerk het'. Van Broekhuizen het in Fiksburg grootgeword waar sy vader van 1882-1894 predikant was. Aangesien daar nie 'n skool was nie het hy eers op 12 jarige leeftyd met die skoolbanke kennis gemaak toe hy na Grey Kollege in Bloemfontein gegaan het.

In 1889 is hy na Stellenbosch om hom by die Kweekskool in te skryf. Hoewel hy geen buitengewone akademiese prestasies behaal het nie, het hy wel op sportgebied uitgeblink ${ }^{2}$. In 1896 word Van Broekhuizen op die laaste oomblik ingesluit in die Springbokspan wat in die vierde toets teen John Hammond se Engelse toerspan gespeel het èn die eerste Springbokspan geword het wat ' $n$ toetswedstryd kon wen ${ }^{3}$.

In 1897 ná die voltooiing van sv studie word Van Broekhuizen gelegitimeer en gaan dan vir ' $n$ jaar voortgesette studie na Holland, terwyl hy ook in Duitsland en Engeland universiteite besoek. Met sy terugkeer na Suid-Afrika maak hy 'n rondreis deur die land. Tydens sy besoek aan Pretoria word hy uitgenooi om te preek en dan word hy beroep as hulpprediker van die verenigde Gemeente te Pretoria ${ }^{4}$. So het hy ook die laaste, donker dae van die ou Republiek beleef.

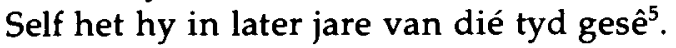

"De oorlog werd de Republiek opgedrongen en het was spreker, toen nog de jongste predikant van de Republiek, die gevraagd werd om de laatste zitting van de Volksraad met gebed te sluiten. Spr. zal dat oogenblik nooit vergeten, toen hy staande naast de grote gryze President de laatste zitting met gebed eindigde."

Tydens die oorlog het hy as predikant en as burger aan die gevegte deelgeneem ${ }^{6}$. As hy probeer om sy moeder, wat ernstig siek in Pretoria was, te besoek, nadat Pretoria reeds geval het, word hy verraai en gevange geneem. Omdat hy weier om die eed van trou aan Engeland af te lê, word hy, omdat hy predikant is, slegs verban uit Suid-Afrika en na Engeland gestuur. Hy slaag daarin om uit Engeland te ontsnap en hou hom dan besig om in Europa en Amerika fondse in te samel vir die vroue en kinders in die konsentrasiekampe.

In Nederland ontmoet hy president Kruger wat dan in Utrecht woon en in die President se gevolg ontmoet hy sy latere vrou, Elsie Francina Eloff, 'n kleindogter van die President met wie hy in 1904 getroud is ${ }^{7}$. In 1903 keer hy terug na Suid-Afrika, maar word deur Lord Milner nie in Transvaal toegelaat nie sodat hy ' $n$ beroep na die 
Gemeente Kuilsrivier aanneem ${ }^{8}$. Nadat Transvaal selfbestuur ontvang het, word hy weer in 1906 na die Ned Hervormde of Gereformeerde Gemeente van Pretoria beroep.

Van Broekhuizen se rustige werksaamheid as predikant word weer deur 'n oorlog onderbreek en wel deur die oorlog van 1914-1918. Gen Louis Botha se besluit om aan die oorlog deel te neem en sy gevolglike inval van Duits Suidwes-Afrika word die oorsaak vir die gewapende protes of rebellie van 1914. Van Broekhuizen, die vurige patriot en oortuigde Afrikaner-nasionalis, kon nie stilbly nie. In September 1914 het Van Broekhuizen gepreek oor die tema Zuid-Afrika en de Oorlog. As teks het hy Num 14:42-43: "Moenie optrek nie, want die Here is nie in julle midde nie ... omdat julle van die Here afvallig geword het."

Diep onder die indruk van wat dit beteken dat hy hom met hierdie preek in 'n emosie-belaaide debat meng, het hy gestel'.

"'t Mag mij kwalik genomen worden, 't mag mij misschien in moeilikheden brengen, maar ' $t$ is nu niet ' $n$ kwestie van personen, maar ' $t$ wel of wee van ons volk, en 't ongehoorzaam zijn aan Gods Woord en Wil! En wij weten allen wat 't betekent als men weigert zich te gedragen overeenkomstig Gods wil en Gods woord."

Van Broekhuizen ontwikkel dan die argument dat die oorlog teen Duits Suidwes-Afrika 'n aggressiewe oorlog en 'n onregmatige oorlog is wat nie met die Woord van God regverdig kan word nie. Hy stel dan ook:

"Aanschouw toch Gods slaande hand. En nu gaan wij nog verder door tegen de wil en 't bevel een aanvallende oorlog te beginnen! Denk aan de laatste jaren. Droogte en armoede is onder ons en in ons maatschappelik leven. Twist en tweedracht in ons politiek leven. Aanschouw toch Gods slaande hand."

Juis omdat die oorlog waarop die regering besluit het as 'n onregmatige oorlog beskou is ${ }^{10}$ was so baie Afrikaners téén die oorlog gekant. Van Broekhuizen het dié argument in sy preek as volg hanteer.

"De overheid bezondigd zich voor God, zo ze zonder oorzaak oorlog voert. Oorlog voert om ongerechtige oorzaak. Nodeloos de levens van tien- en honderdtallen waagt! Al wat niet uit de roeping van de door God aan de overheid verleende macht voortvloeit, is moord! En vreeslik zal 'n oordeel zijn dat eens komen zal over die vorsten en staatslieden, die uit lust tot oorlog, uit eerzucht, uit zucht tot verovering, volk en vaderland in 'n bloedige oorlog dompelen." 
Daarom het Van Broekhuizen sy preek ook beëindig met 'n oproep dat elkeen goed moet nadink oor wat hy moet doen. Dan eindig hy -

"Maar als Evangelie Dienaar, als zoon van mijn volk, als man van geweten, is alleen de vraag: wat wil God? En daar zeg ik u op grond van 't Woord, op grond van de geschiedenis, op grond van waarheid en recht: Trek niet op ..."

Hierdie preek wat in Pretoria beroering veroorsaak het en in 'n sekere sin óók gegeld het as Van Broekhuizen se "afskeidspreek" van sy gemeente het vir hom net één pad oopgelaat en dit was aansluiting by die gewapende protes teen die oorlog. Hierdie gewapende protes of rebellie het, soos bekend, volkome misluk en het geëindig met die teregstelling van komdt. Jopie Fourie in Pretoria, die dood van die generaals De la Rey en Beyers, terwyl die generaals Christiaan de Wet, Chris Muller en Kemp gevange geneem is. Slegs generaal Manie Maritz wat na Duits Suidwes-Afrika uitgewyk het, het die tronk vrygespring. Die ander "rebelle" is gevang, in die tronk gestop en meestal ter dood veroordeel. Dié lot het Van Broekhuizen óók getref. Sy doodstraf is egter tot twee jaar gevangenisstraf gewysig. Wat vir hom 'n harde slag in die gevangenis was, was die feit dat sy gemeente nié kans gesien het om sy gesin te versorg nie. Hulle moes uit die pastorie padgee maar kon gelukkig by familie versorging vind. Dit het ook beteken dat hy nie kans gesien het om langer die Ned Hervormde of Gereformeerde gemeente te bedien nie ${ }^{11}$.

Nadat Van Broekhuizen uit die tronk vrygelaat is, is hy deur die owerheid voorlopig verbied om te preek en dit het beteken dat hy nie weer sy ampswerk kon opvat nie. Sy mede-rebel en selmaat in die tronk, ds HCM Fourie, predikant te Bronkhorstspruit en ander vooraanstaande Afrikaners in ons Kerk, het toe die plan opgevat om Van Broekhuizen na die Hervormde Gemeente van Pretoria te beroep. Die Gemeente het vakant geword omdat dr JHJA Greyvenstein die gemeentewerk neergelê het om die professoraat van die nuutgestigte Teologiese Opleiding te aanvaar. Dié beroep was vir Van Broekhuizen ' $n$ besondere gebeure en hy het dit dan ook met groot dank aanvaar. Self het hy daarvan gesê:

"In die diepte van ellende kwam het beroep van deze gemeente. Dit heeft spreker sterk getroffen. In die tyd van verguizing, na de tyd van gevangenis, werd op spreker het beroep van deze gemeente gebracht."

Op die Kerkraadsvergadering van 2 April 1917, waar oor die beroep gehandel is, is veral die persone van ds Simon Vermooten en Van Broekhuizen bespreek. Die feit dat Van Broekhuizen rebel was en daarby so 'n uitgesproke Afrikaner-nasionalis het by sommige die vraag laat ontstaan of dit in die politieke klimaat en toestand van die 
dag, wel raadsaam sou wees om Van Broekhuizen te beroep. Die feit egter dat Van Broekhuizen 'n ervare en gerespekteerde predikant in Pretoria was, het op die ou end die deurslag gegee ${ }^{12}$. Die feit dat Van Broekhuizen op daardie stadium nog formeel as ' $n$ diensdoende predikant van die Ned Hervormde of Gereformeerde Kerk gegeld het, is skaars in die diskussie genoem.

In 'n sekere sin was dit óók verstaanbaar want tot op daardie stadium was ons Kerk nog volkome afhanklik van ander kerke vir sy predikante en dit het in die praktyk beteken dat ò ' $n$ predikant uit Nederland ò 'n predikant uit die NG Kerk-familie beroep moes word as die predikantegetal in ons Kerk aangevul moes word ${ }^{13}$.

Dit is opvallend dat die Kerkraad, voor of tydens die beroep, nie in verbinding met die Kommissie van die Algemene Kerkvergadering was oor die beroep van Van Broekhuizen nie. Die rede hiervoor word miskien duidelik in 'n opmerking van oudl ADW Wolmarans, op 'n Kerkraadsvergadering van 25 Mei 1917, nádat die Kommissie geweier het om dié beroep goed te keur. Dan stel Wolmarans:

"Ik kan niet begrijpen waarom de Algemene Kommissie verlof weigert op welke grond. Reeds twee maal was ds van Broekhuizen beroepen, te Zeerust en te Pretoria. Toen was er geen bezwaar. De derde maal maakt men bezwaar."

Dié gebrek aan oorlegpleging rondom die beroep van Van Broekhuizen het ' $n$ yslike herrie veroorsaak en die uiteinde van die saak was dat 'n buitengewone Algemene Kerkvergadering op 20 November 1917 moes bymekaarkom om die hele saak uit te stryk.

\section{DIE FEITE VAN DIE SAAK}

Dit is opmerklik dat die Wetten en Bepalingen voor de Nederduitsch Hervormde Kerk van Zuid-Afrika die hele saak van die beroep van predikante uit ander kerke nié sorgvuldig omskryf het nie. Dit was eintlik in die situasie van destyds, 'n saak wat omskryf moes gewees het. In die Wetten en Bepalingen wat in 1917 gegeld het, was daar slegs 'n paar artikels wat in hierdie verband ter sake was.

Hulle was: art 57 wat gelui het:

"Als predikant in eenige gemeente der Nederduitsch Hervormde Kerk zullen worden toegelaten alleen zij:

(a) die door de kerk zelve tot predikanten zijn opgeleid;

(b) die met medeweten en goedvinden der Commissie der Algemeene Kerkvergadering elders zijn opgeleid, aan ene wettig erkende Hoogeschool of Kweekschool en door haar zijn bevoegd verklaard. 
De Commissie der Algemeene Kerkvergadering is bevoegd hierop uitzondering toe te laten, indien vooraf hare goedkeuring is gevraagd."

Daarby kom dan ook nog art 24 waar die ter saaklike bewoording lui:

“De Commissie der Algemeene Kerkvergadering heeft het recht

(c) de bekwaamheid en geschiktheid te onderzoeken van predikanten en proponenten van andere kerkgenootschappen, die tot de Nederduitsch Hervormde Kerk wenschen over te komen; ..."

Die hele saak het as volg verloop. Op 2 April 1917 het die Kerkraad onder voorsitterskap van die konsulent, ds A Murray van Rustenburg, byeengekom. Met dié vergadering is Van Broekhuizen toe beroep. Die beroepsbrief is nie direk aan Van Broekhuizen gestuur nie. Eers is daar 'n skrywe aan die Kommissie van die Algemene Kerkvergadering gestuur om in terme van art 57 van die Wetten en Bepalingen hulle goedkeuring vir die beroep te vra.

Uit die kerklike praktyk van daardie dae is dit moeilik om vas te stel wat presies die gebruik was ${ }^{14}$. Hoewel dit nie so direk geformuleer was nie, was die kerklike praktyk rondom art 57, wanneer dit toegepas is, dat 'n kerkraad éérs onder art 57 toestemming moes verkry om iemand uit ' $n$ ander kerk te beroep. Nadat die toestemming verleen is, kon dan beroep word.

Ds A Murray, die konsulent, het die Wet egter so uitgelê dat daar éérs beroep kon word en daarna moes goedkeuring aangevra word. Hoewel art 57 stel dat die Kommissie uitsonderings ten opsigte van art 57 kan toelaat "indien vooraf hare goedkeuring is gevraagd," is dit tog nié pertinent gestel wat presies met die begrip vooraf bedoel word nie. Dit kan òf vóór die beroep òf vóór die bevestiging as predikant wees ${ }^{15}$ ! Die Kommissie van die Algemene Kerkvergadering het op 18 April 1917 vergader en die versoek van die Kerkraad bespreek. Dan word besluit ${ }^{16}$ :

"De Algemeene Commissie is van oordeel dat de kerkeraad van Pretoria gehandeld heeft in strijd met art 57 al 2 en besluit dat zij op grond daarvan de gevraagde goedkeuring niet kan geven: en is bovendien van oordeel dat de toestand van de kerk voor het tegenwoordige niet vereischt, om uitzondering op art 57 letter $a$ en $b$ toe te laten ..."

Die Kerkraad het nie' $n$ besondere waardering vir hierdie besluit van die Kommissie ontwikkel nie en het onmiddellik beswaar aangeteken teen die besluit. In ' $n$ lang brief aan die Kommissie stel die Kerkraad, onder andere: 
"Uw besluit heeft ontroering verwekt die tot in de verste deelen der Gemeente is doorgedrongen. Ook gemeenteleden die van hun voorkeur voor een andere predikant hadden doen blyken, tonen zich even gevoelig om niet te zeggen verontwaardigd en dringen er by de Kerkeraad krachtig op aan niet te berusten in het besluit der Algemeen Commissie maar alle pogingen in het werk te stellen om genoemd besluit ingetrokken te krijgen.

Dit het die spanning tussen die Kerkraad en die Kommissie nié verminder nie. Omdat die Kerkraad klaarblyklik nie van plan was om die beslissing van die Kommissie sonder meer te aanvaar nie, is daar toe ' $n$ vergadering van die Kerkraad met lede van die Kommissie op 25 Mei 1917 gehou.

Tydens dié vergadering het die rede wáárom die Kommissie van die Algemene Kerkvergadering die beroep afgewys het, na vore gekom. In 'n latere verslag aan die Algemene Kerkvergadering is die saak só gestel ${ }^{17}$ :

"De leden van de Algemene Commissie hebben gedurende de samenspreking de leden van de Kerkeraad doen verstaan dat de Algemeene Commissie zelfs met de beste wil niet bij machte was om de onwettige handelwijze van de Kerkeraad in zake de beroeping goed te keuren of wettig te verklaren.

Mocht de Algemene Vergadering besluiten om Ds van Broekhuizen niet toe te laten, dan wordt er een klein vuurtje ontstoken in de gemeente Pretoria en miskien hier en daar elders bij enkele leden onzer kerk, doch daar dreigt ons een groot vuur indien wij hem wel toelaten $\mathrm{nl}$ 't vuur van zogenaamde Kerkvereeniging 1885-1887. Indien wij dat groot vuur terug wensen, laat dan enige predikanten van buiten toe in onze kerk. Verder heeft de Algemene Commissie getracht om Art 57 uit te leggen in de geest van de Alg Verg van 1909, waar uitdrukkelijk uitgesproken is dat het de bedoeling was om niet weer iedereen van buiten toe te laten, maar de deur kleiner te maken; en volgens de opvatting van de leden der Nederduits Hervormde Kerk daarin geboren en die nog nooit een enkele dag daar buiten zijn geweest."

Die Kerkraad het egter tydens die samesprekings van 25 Mei onder die indruk gekom dat die Kommissie bereid was om wél die Kerkraad se beroep goed te keur indien Van Broekhuizen formeel sou aansluit as lidmaat by die Gemeente èn indien hy hom bereid sou verklaar om in terme van art 24 voor die Kommissie te verskyn sodat die Kommissie na sy "bekwaamheid en geschiktheid" ondersoek kon doen. Op grond van hierdie versoeningsvoorstel van ds LE Brandt het Van Broekhuizen toe op 28 Mei 1917 sy bewys van 
lidmaatskap ingehandig en hom bereid verklaar om hom te onderwerp aan ' $n$ ondersoek soos art 24c van die Wetten en Bepalingen vereis ${ }^{18}$.

Die Kerkraad was oortuig dat daar nou géén verskilpunt meer was nie en dat die goedkeuring vir die beroep nou geen probleme meer sal skep nie ${ }^{19}$. Maar dit sou nie gebeur nie. Met die vergadering van die Kommissie van die Algemene Kerkvergadering van 28 Junie 1917 het dit veral geblyk dat ds LE Brandt, die voorsitter, ds Jac van Belkum, die skriba, en ds JJ Prinsloo, die predikantslid van die Kommissie tog nog skerp gekant was teen die optrede van die Kerkraad van Pretoria. Op dié vergadering van die Kommissie het oudl ADW Wolmarans, een van die ouderlinglede van die Kommissie, die saak van die Kerkraad baie sterk bepleit ${ }^{20}$. Ondanks die groot gewig wat Wolmarans se opvattings gewoonlik gedra het, het die Kommissie nie sy voorstel aanvaar nie. ' $n$ Voorstel van ds Brandt en ds Van Belkum is aanvaar wat gestel het:

"Overwogen hebbende dat er groot verschil van gevoelen bestaat over de toepassing van Art 2, 24 en 57 der wetten, en verder dat er groot gevaar dreigt voor de kerk als een geheel en de gemeente Pretoria in het byzonder, besluit, aangezien zy de verantwoordelikheid in deze moeilike zaak niet op zich wil nemen, eene Algemeene Kerkvergadering op te roepen tegen 30 October 1917 om zich duidelijk uit te spreken over de beteekenis en de toepassing van art 24 en 57 der Wet en hiervan aan den Kerkeraad van Pretoria kennis te geven."

Hierdie besluit van die Kommissie het by die Kerkraad die indruk laat ontstaan dat die Kommissie ánders optree as wat die aanvaarde gebruik in die Kerk was. Daarom het die Kerkraad op 6 Julie 1917 besluit:

"dat de Kerkeraad zijn diepe teleurstelling uitspreekt over de houding van de Alg. Komm. tegenover de Kerkeraad in deze zaak; dat de Kerkeraad ongenegen is na alles gedaan te hebben, wat de Alg Komm wenste, nu nog verder de belangen van de Gemeente op te offeren aan de willekeurige handelingen van de Alg Komm door de beroeping nog weer een vier maanden op te houden; ..."

en om sy beroepsbrief aan Van Broekhuizen te stuur.

In die omstandighede waarin Van Broekhuizen verkeer het, het hy dié beroep nie alleen met groot dankbaarheid ontvang nie, maar dit ook onmiddellik aanvaar. Die Kerkraad het daarop besluit dat Van Broekhuizen op 5 Augustus 1917 bevestig sou word deur die konsulent nadat die Kerkraad al die stukke wat vir die bevestiging nodig was, nagegaan het. 
Met hierdie besluit het die Kerkraad beslis buite sy bevoegdhede gehandel. Hoewel in die dispuut oor die toepassing van art 57 die Kerkraad nog 'n saak kon uitmaak, het die besluit om Van Broekhuizen te bevestig ' $n$ reeks van kerklike reëls en gebruike oortree.

In die eerste plek was Van Broekhuizen nie gelegitimeer nie en het hy ook nie die proponentsformule onderteken nie. Daarsonder was dit net nie moontlik om hom wettiglik te bevestig nie.

In die tweede plek was daar, sowel uit die gemeente as van die kant van die Kommissie van die Algemene Kerkvergadering gewigtige besware teen die bevestiging van Van Broekhuizen. So lank daardie besware bestaan het, was daar nie 'n moontlikheid om hom te bevestig nie ${ }^{21}$. In die derde plek het die Kerkraad baie duidelik sy bevoegdhede oortree deur te doen wat nie binne sy bevoegdheidsmoontlikhede gelê het nie.

Tog is Van Broekhuizen toe op 5 Augustus 1917 deur die konsulent ds A Murray in teenwoordigheid van ds HCM Fourie bevestig. In sy intreepreek het Van Broekhuizen gestel ${ }^{22}$ :

"Gedachten overstelpen mij, Hervormde Gemeente van Pretoria, die ik thans mag toespreken als mijn gemeente. Over twee maanden zullen drie jaren voorbij zijn gegaan dat ik laatst als Evangelie Dienaar in deze stad optrad. Drie jaren van smart en droefheid, van angst en lijden; drie jaren die soms als drie eeuwen van stikdonkere duisternis voor mij waren. En toch gespaard, bewaard, gedragen door Gods lankmoedigheid om nu andermaal de herderstaf onder toezicht en leiding van den groten Opperherder op te nemen. Niet langer in dezelfde gemeente in dezelfde Kerk, maar toch nog in de Gemeente in de Kerk van de Koning der Kerken, onze Heere Jezus Christus! Mijn positie is eenigszins anders dan gewoonlijk; ik heb geen afscheid van een gemeente behoeven te nemen. Het wordt al drie jaar in October dat ik zonder gemeente ben ...

Tog heb ik afscheid moeten nemen niet alleen van een gemeente die ik jaren heb gediend, maar vooral moeten breken met een Kerk waar ik bijna 20 jaar Evangeliedienaar van was!

... En nu sta ik thans hier voor $u$, gemeente van Pretoria, met een dankbaar hart, dat $\mathrm{Hij} \mathrm{mij} \mathrm{andermaal} \mathrm{geroepen} \mathrm{heeft} \mathrm{in}$ deze gemeente en in deze onze stad om u de heilware des Evangelies te verkondigen ...

Uit die hele preek straal Van Broekhuizen se dankbaarheid dat hy weer as predikant in 'n gemeente werksaam mag wees èn sy toewyding aan sy roeping en opdrag. Tog bly dit merkwaardig dat hy toegelaat het dat hy onder die merkwaardige omstandighede bevestig is. Waarskynlik het hy hom in sy optrede grotendeels laat lei deur oudl ADW Wolmarans wat in hierdie saak skerp standpunt téén die 
Kommissie ingeneem het en sy goedkeuring aan die bevestiging van Van Broekhuizen gegee het.

Die Kommissie van die Algemene Kerkvergadering het, nieteenstaande die nogal uittartende optrede van die Kerkraad van Pretoria, nie skerp gereageer nie $^{23}$. Ter voorbereiding van die Algemene Kerkvergadering het die Kommissie die samewerking van die Kerkraad gekry om 'n kommissie van juriste aan te stel om 'n uitleg van die omstrede artikels van die Wetten en Bepalingen te gee. Dié "rechtskundige kommissie" is toe gevorm deur die juriste J van Hoytema, WJ van Zyl en Tielman Roos.

In sy advies het die drie juriste onder andere gestel:

"Het is ons duidelik, dat onder Art 113 kunnen alleen beroepen word en als predikanten, alle predikanten alreeds in de Hervormde kerk, en zodanige andere personen, als onder Art 57 toegelaten zijn als predikanten in voornoemde kerk. Het wordt derhalve nodig om uitleg te geven van Art 57.

In de eerste plaats kunnen onder subsectie A van dit Art personen toegelaten worden, die door de kerk zelve zyn opgeleid tot predikanten.

Onder subsectie B zulke personen, die met medeweten en goedvinden der Algemene Kommissie elders zyn opgeleid aan een wettig erkende Hoogeschool of Kweekschool, en door de Kommissie zyn bevoegd verklaard.

Dit stelt de algemene regel vast voor de toelating van personen als predikanten in de kerk. Maar op deze regel wordt een uitzondering gemaakt in de laatste regels van Art 57. De Kommissie word namelik bevoegdheid gegeven om uitzondering te maken op deze algemene regel. De Kommissie kan dus naar goedvinden een uitzondering maken of niet, en wanneer zy geen uitzondering wil toelaten kan een gemeente of lidmaat daarvan zich niet daarover by de Kommissie beklagen."

Verder het die juriste daarop gewys dat 'n lidmaat hom wél op 'n Algemene Kerkvergadering kan beroep wat dan ook die toepassing van art $57 \mathrm{kan}$ oorweeg sonder om daardeur gebind te wees deur die beslissings van die Algemene Kommissie.

Op 'n vraag wat deur die Kerkraad aan die juriste gestel is, het hulle geantwoord:

"... maar het moet duidelik verstaan worden, dat waar in stryd gehandeld werd Art. 57 zodanig leraar niet kan beschouwd worden als bevestigd. De bevestiging is van geen waarde. Die Algemeene Kerkvergadering alleen kan de bevestiging bekrachtigen." 
Die juriste het in hulle antwoord duidelik aangetoon dat die Kerkraad nie die kerkregtelik-korrekte weg bewandel het nie en sodoende ' $n$ hele dilemma veroorsaak het.

Tog is dit duidelik dat die juriste alléén die Wetten en Bepalingen uitgelê het en nié daarop gelet het dat die Kommissie van die Algemene Kerkvergadering nie in elke voorkomende geval art 57 toegepas het èn dit ook nie altyd konsekwent toegepas het nie. Sodoende het die Kommissie, ondanks die duidelike opdrag van art 23 , sélf die geldigheid van art 57 ondermyn ${ }^{32}$. Die Kerkraad het egter nooit dié argument voor die juriste gelê nie sodat hulle nié daaroor 'n mening gegee het nie. Dit is egter duidelik dat die Kerkraad hom laat lei het deur die kerklike praktyk waarvolgens art 57 alleen ' $n$ betreklike geldigheid gehad het. Dit kan dus gestel word dat die Kommissie self, tot in ' $n$ hoë mate, aanleiding gegee het dat art 57 nie ernstig opgeneem is nie. In hierdie geval het die Kommissie hom egter weer op die letter van die wet én die diskresie wat kragtens art 57 aan hom toegeken is, vasgehou om die beroep van Van Broekhuizen te probeer blokkeer.

\section{DIE ALGEMENE KERKVERGADERING VAN 20 NOVEMBER 1917}

Die Algemene Kerkvergadering het op 20 November in die Kerkgebou van Pretoria byeengekom en het uit 9 predikante en 64 kerkraadslede bestaan. Die voorsitter, ds LE Brandt, het daarop gewys dat die vergadering opgeroep is om geraadpleeg te word en dat hier nie ' $n$ appèlsaak behandel word nie. Verder is besluit dat die plaasvervangende voorsitter en skriba die vergadering moet lei en so het dit gebeur dat ds Simon Vermooten as voorsitter moes optree en ds HCM Fourie as skriba.

$\mathrm{Na}$ ' $\mathrm{n}$ aanvanklik debat het die vergadering besluit:

"Deze vergadering kennis genomen hebbende van het rechtsadvies inzake uitleg van Art 57 en andere van onze Kerkwet, besluit hiermede dat de Algemene Commissie in zake beroeping van Ds van Broekhuisen heeft gehandeld en is opgetreden geheel binnen de perken van onze Kerkwet, dat in deze zaak geen blaam rust op onze Algemene Commissie, dat de uitleg van de Artikels door de Algemene Commissie de juiste is, en dat de handelwijze van de kerkeraad van Pretoria op zijn eigen merieten zal behandeld worden."

Die feit dat die woordvoerders van die Kerkraad van Pretoria die regsadvies aanvaar het en ook erken het dat hulle insien dat hulle kerkregtelik verkeerd opgetree het, het baie gedoen om die lug te suiwer. 
Die volgende vraag was toe of die Algemene Vergadering bereid sou wees om die optrede van die Kerkraad, met die beroep èn die bevestiging van Van Broekhuizen, agterna te wettig deur dit goed te keur.

Uiteindelik het die vergadering met 43 stemme teen 30 'n besluit aanvaar wat gelui het:

"Deze vergadering, alle omstandigheden in overweging genomen hebbende, besluit dat niettegenstaande de kerkeraad van Pretoria niet voldaan had aan de vereisten der Kerkwet in verband met het beroepen van predikanten, toch onder omstandigheden het bevestigen van Ds van Broekhuysen te bekrachtigen en goed te keuren."

Daarmee was die hele saak afgehandel en is die optrede van die Kerkraad van Pretoria gewettig. Van Broekhuizen is dan ook nog na die vergadering genooi en deur die voorsitter verwelkom as predikant van die Kerk. Van Broekhuizen het met gepaste woorde sy dank uitgespreek en gestel:

"... ik ga met hart en ziel mij geven aan de Kerk. Wil my dan ook zo ontvangen. Ik vertrouw op Gods hulp om getrouw te zijn zowel in 't kleine als in het grote."

Aan daardie belofte het Van Broekhuizen, gedurende sy ampstermyn in die Kerk, nooit ontrou geword nie.

\section{ENKELE OPMERKINGS}

Dit is duidelik, in hierdie hele geval, dat die Kommissie van die Algemene Kerkvergadering op grond van die diskresie wat deur art 57 aan hom toegeken is, die bevoegdheid gehad het om op te tree soos hy opgetree het. Wat merkwaardig is en bly is die feit dat die motiewe vir die Kommissie se optrede redelik bedek bly in die hele geskil. In sy besluit om 'n Algemene Kerkvergadering op te roep, stel die Kommissie slegs "dat er groot gevaar dreigt voor de kerk als een geheel en de gemeente Pretoria in het byzonder." Die "groot gevaar" het, as die diskussie op die Algemene Vergadering gevolg word om twee punte gesirkel naamlik:

1. Dat goedkeuring van die optrede van die Kerkraad 'n moeilike presedent sou skep en die moontlikheid dus sou bestaan dat art 57 as ' $t$ ware opgehef sou word. Dit sou beteken dat die kerkrade van vakante gemeentes vryelik predikante uit ander kerke sou kon beroep. Dit sou op sy beurt weer beteken dat die pasgestigte eie opleiding op dié manier eintlik weer as oorbodig of ontoereikend verklaar sou word. 
2. Die beroep van ' $n$ Verenigde predikant èn die aanvaarding daarvan, sou kon beteken dat daar weer ' $n$ toestroming van Verenigde predikante na die Hervormde Kerk sou kom. Dit sou, so was die argument, weer dieselfde situasie as in 1885 kon skep toe daar ook 'n meerderheid van Stellenbosse predikante in die Hervormde Kerk was en die Kerk hom toe in die mislukte Kerkvereniging begewe het.

Merkwaardig genoeg is die politieke argumente nêrens gebruik nie, hoewel dit tog ook'n onuitgesproke rol moes gespeel het. Daar was immers geen twyfel waar Van Broekhuizen in die politiek gestaan het en daarby het sy eggenote ook nie ' $n$ onbeduidende rol in die Nasionale Party wat in 1914 gestig is, gespeel nie. Hoewel daar geen pertinente bewyse daarvoor bestaan nie, word die indruk tog geskep dat Van Broekhuizen se uitgesproke standpunt en die feit dat hy 'n rebel was, hom vir die Kommissie van die Algemene Kerkvergadering minder aanvaarbaar gemaak het. Dié argument is egter nie gebruik nie en in die plek dáárvan is die argument gebruik dat Van Broekhuizen as 'n Verenigde predikant ons Kerk weer op die pad van Kerkvereniging sou lei. Dit is egter alleen 'n vermoede dat die politieke argumente hier 'n groot rol gespeel het. Wat daarteen pleit is die feit dat ds JJ Kühn, wat sy gemeente verlaat het om as veldprediker genl Louis Botha se invalsmag in Duits Suidwes-Afrika te vergesel, so 'n versoenende rol gespeel het en al sy gewig ingegooi het om 'n "vrywaringswet" aangeneem te kry wat die rebel Van Broekhuizen sou toelaat in die predikantekorps van die Hervormde Kerk.

Die feit dat die Kommissie self, in sy optrede teenoor die Kerkraad van Pretoria, nie met kragtige én grondige argumente aangetoon het wát die groot gevaar was nie, het oudl ADW Wolmarans laat sêt $\hat{e}^{24}$ :

"De drie predikanten der Algemeene Commissie schijnen er sterk voor te zijn om de zaak af te keuren. Hij hoopt echter dat zij hun heerszucht, eerzucht en hoogmoed niet zullen stellen boven de belangen der kerk."

Dit skep die indruk dat hier tog ' $n$ redelike ernstige kommunikasiestoornis was en dat dit aan die grond van die hele saak gelê het. Dit was veral ds JJ Prinsloo wat die skerp vooroordeel wat inderdaad in die Hervormde Kerk teen Verenigde predikante bestaan het, onder woorde gebring het toe hy onder andere gestel het ${ }^{25}$ :

"Vooraf wil hij erkennen dat hij bepaald onverzoenlijk is tegen alles wat in strijd is met de belangen onzer Kerk, ook in dit geval van Pretoria ... Ds van Broekhuysen is onwettig bevestigd en hij is bang voor meer gevaar als Ds van Broekhuysen konsulent zoo worden van een andere gemeente en ook daar zijn invloed laat gelden. Het einde van zulk predikanten kan 
zijn als dat van Ds Bosman, en het is moeilik voor spreker om met sulke predikanten saam te werken. Er is nog geen andere reden gegeven waarom Ds van Broekhuysen een wenselik persoon is voor onze Kerk. Het klein vuurtje zal branden, wanneer Ds van Broekhuysen niet toegelaten wordt, maar het grote vuur zal komen wanneer vereniging komt."

Ds Jac van Belkum het ook op dié snaar getokkel, toe hy gestel het ${ }^{26}$ : "Wie was de eerste predikant in Transvaal toen alles nog zwaar ging? Ds van der Hoff. En nu wordt hij als een dronkaard voorgesteld. Maar op zijn sterfbed heeft hij geprofeteerd dat na zijn dood zijn werk zou vernietigd worden omdat er vereniging zou komen. Later is Ds Bosman gekomen en heeft het voorstel gemaakt om te verenigen ... Er bestond een gevaar dat de Westelike Ring op de Algemene Vergadering zou komen met een voorstel om te verenigen ...

Tog was dit duidelik dat hierdie vermoedens nié aan die persoon van Van Broekhuizen gekoppel kon word nie en dit het meegebring dat hierdie argumente nie veel krag gehad het nie. Dit was dan ook verstaanbaar, want dit was nie maklik om die Algemene Vergadering te oortuig dat ' $n$ man soos oudl ADW Wolmarans van Pretoria willens en wetens 'n Verenigde predikant die Kerk wou insmokkel om sodoende ' $n$ kerkvereniging voor te berei nie.

Daarby was dit ook duidelik dat Van Broekhuizen, wat nie toegelaat was om sy dienswerk in die Verenigde gemeente van Pretoria voort te sit nie, nie beskou kon word as iemand wat juis die saak van die Verenigde Kerk in die Hervormde Kerk sou kom bevorder nie.

Deur die argument te voer dat Van Broekhuizen as Verenigde predikant nie aanvaarbaar is nie, het ds JJ Prinsloo en ds Jac van Belkum nie die Algemene Vergadering oortuig nie en waarskynlik omdat die Vergadering besef het dat dit nie die werklike rede was waarom dit gegaan het nie, het die Vergadering ook hulle standpunt verwerp.

Indien die Kommissie van die Algemene Kerkvergadering in hierdie geval met 'n bietjie méér diplomasie en mensekennis opgetree het, sou die hele saak van die beroep van Van Broekhuizen nooit so 'n opsienbarende nasleep gehad het nie. Dit bly egter interessant om vas te stel dat die Kerkraad van Pretoria uiteindelik tóg sy sin gekry het, al moes 'n Algemene Kerkvergadering byeenkom om sy optrede te wettig. Hoewel dit ' $n$ interessante geval is, is dit beslis nie aanbevelens- of navolgingswaardig nie.

\section{LATERE LEWE VAN VAN BROEKHUIZEN}

Van Broekhuizen het tot in 1925 in Pretoria gestaan en met groot toewyding in die Kerk en in sy gemeente gewerk. As kanselredenaar 
van formaat, vurige vaderlander en beginselvaste Afrikaner het hy geweldig baie vir die Afrikaner in die stad beteken. Hoewel hy voortdurend "politieke preke" gehou het, wat veral die SAP-koerant De Volksstem hier in Pretoria dikwels van verontwaardiging laat stik het, het hy onverstoord sy gang gegaan.

Vroeg in 1922 het Van Broekhuizen nog aan die Rijksuniversiteit te Leiden gepromoveer tot doctor theologiae op 'n proefskrif Die Wordingsgeskiedenis van die Hollandse Kerke in Suid-Afrika, 1652-1804.

In Februarie 1924 het Van Broekhuizen, onder blyke van groot belangstelling, sy 25-jarige ampsjubileum in Pretoria gevier. Tydens sy preek het hy gestel ${ }^{28}$ :

"De roeping in onze tyd is nimmer of nooit te kruipen voor de machtigen; de ryken niet te vleien, de armen niet te minachten. Wie Gods Woord draait naar de wil en wens der ryken, pleegt mensendienst. Wy moeten nooit vergeten, dat de evangeliedienaar, die naar eigen roem streeft, mensen probeert te behagen, is geen dienaar van Jezus Christus."

Daarmee het Van Broekhuizen in 'n hoë mate homself geteken. Hy was ' $n$ man met 'n sterk persoonlikheid, groot en fors van gestalte, beginselvas en toegewyd. Maar terselfdertyd 'n man wat alles feil gehad het vir die kerk en die Afrikanervolk wat hy met soveel oorgawe gedien het $t^{29}$.

In 1925 het Van Broekhuizen as predikant bedank nadat hy die Volksraadsetel Pretoria-Distrik (Suid) op 15 September vir die Nasionale Party van genl Hertzog met 'n meerderheid van 350 stemme verower het ${ }^{27}$. In sy afskeidspreek, gehou op 4 Oktober 1925, het Van Broekhuizen daarop gewys dat hy nie oral in ons Kerk sonder meer aanvaar is nie. Tog het hy met ywer en dankbaarheid in die Kerk gewerk en het hy veral sy dank uitgespreek teenoor kerkraad en gemeente wat hom so begestaan en op die hande gedra het. Hy het afgesluit ${ }^{30}$ :

"En nou Kerke, gemeentes, vriende: Vaarwel! Na byna 27-jarige diens as Evangeliedienaar, gaan ek heen. Baie afskeid moes ek al geneem het. Hierdie keer egter nie as gevangene en rebel nie. Nou egter val dit my swaar, bitter swaar. My hart ween en treur. Dank, duisendmaal dank, ook namens vrou en kinders. Met die Here God aan my sy gaan ek die toekoms in. "hetzy dat wy leven, hetzy dat wy sterven, wy zyn des Heeren."

Van Broekhuizen, wat kerk en volk nie as aparte groothede gesien het nie, maar as twee kante van dieselfde saak, was oortuig daarvan dat hy as politikus sou kon voortgaan om vanuit dieselfde voorveronderstellings, vanuit dieselfde geloof waaruit hy as predikant geleef en gewerk het, sy volk en sy kerk te dien. 
So het daar 'n einde gekom aan Van Broekhuizen se kerklike loopbaan. As politikus het hy later, met die algemene verkiesings van 1929 en 1933 weer die kiesafdeling Wonderboom vir die Nasionale Party van genl Hertzog verower. Vroeg in 1933 is Van Broekhuizen egter aangestel as die Unie se Gesant en Gevolmagtigde Minister by die Nederlandse en Belgiese regerings. Hierdie hoë amp het hy tot in 1941 beklee toe hy as 70- jarige die amp neergelê en na SuidAfrika teruggekeer het.

Terug in Suid-Afrika het hy hom grotendeels uit die openbare lewe teruggetrek en stil en rustig in Pretoria gewoon tot aan sy dood in September 1953. Hy is in Pretoria deur ds Simon Vermooten, sy opvolger as predikant van Pretoria, begrawe.

\section{Aantekeninge}

1. Burgerlijke Stand, Rijssen (uittreksel uit die geboorte-akte). In 'n onderhoud met 'n Nederlandse koerant in 1930 (Koerantknipsel in die NH Kerkargief, SPE x 11/37) stel Van Broekhuizen: "Voor zijn gezondheid kwam mijn vader uit Zuid-Afrika tijdelijk naar Nederland. Hij stond hier een paar jaar, nl. in Rijssen en Oosterbierum, en daarna is hij weer naar Zuid-Afrika vertrokken." Vergelyk ook PL Olivier, Ons Gemeentelike Feesalbum, Kaapstad - Pretoria 1952, bl 321.

2. In sy herinneringe (SPE $\times 11 / 37$ ) stel hy: Voetbal, tennis, cricket, loopen en kogelstooten waren mijn lievelingsvakken aan de universiteit.

3. C Greyvenstein, Sprinkbok Saga, Cape Town 1978, p. 26.

4. Gedenkboek van die Teologiese Seminarie (NG Kerk) Stellenbosch, Stellenbosch 1934, bl 256.

In sy preek met die herdenking van sy 25 -jarige ampsjubileum het hy gestel (Ons Vaderland, 18 Februarie 1924): Spr. had eigelik 'n Vrystaatse gemeente willen dienen, omdat zyn vader daar ook z'n 25-jarige ambstyd gevierd had. Maar de roeping lag hier, te Pretoria. Dit was de leiding van God, en 't is ' $n$ grote geruststelling voor de prediker: God roept hem; hy kiest niet zelf. God stoot hem uit in Zyn wyngaard en op Zyn plaats. "In dien gy het gewillig doet, zo hebt gy loon." God dreef spreker naar Pretoria. In Oktober 1898 kwam spr. reeds hier, maar de bevestiging vond eerst plaats in Febr. 1899, ...

5. Ons Vaderland, 12 Feb 1924.

6. SPE $\times 11 / 37$ : Ik ben predikant gebleven (tydens die oorlog), maar ik heb tevens mijn geweer gedragen, en het niet zuinig gebruikt ook. Een tijdlang ben ek als verkenner opgetreden onder kapitein Theron, de ooren en oogen van generaal de Wet.

7. DW Krüger, Suid-Afrikaanse Biografiese Woordeboek, Kaapstad 1977, Dl III, bl 817-818.

8. Van Broekhuizen was nie 'n man wat sy mening, in gevaarlike tye onder stoele of banke weggesteek het nie. So bots hy ook in die Kaap met die owerhede. Daarvan vertel hy (Ons Vaderland, 12 Feb 1924): Hy predikte 't evangelie in de Kaap. Ook te Robertson, waar hy bad voor Pres Steyn, die toen ernstig ziek was, en ook gedacht hy aan Pres Kruger. Spr werd daardoor voor 't hof gebracht, wegens seditie, maar de hoofdrechten kwam zelf naar Worcester om in de zaak als rechter op te treden en spr werd vrygesproken. Later heeft de hoofdrechter spr gevraagd of hy zich nog die dwaas van ' $n$ prokureur-generaal herinnerde, die hem voor seditie had laten opbrengen.

9. De Volkstem, 15 September 1914.

10. Die argument is baie skerp gestel deur almal wat teen die inval in Duits SWA gekant was en dit is opmerklik dat hierdie billike argument nooit bevredigend beantwoord is nie. 
11. Ons Vaderland, 12 Februarie 1924. Hier stel Van Broekhuizen: Daarom kon spr onmogelik langer dienen waar hy gediend had, toen getoond werd, dat daar geen liefde maar alleen verwerping van zekere kant was.

12. Kerkraadsnotule, Ned Herv Gemeente Pretoria, 2 April 1917.

13. Hier kan daarop gelet word dat hoewel die eie Opleiding in 1917 ingestel is, dit nie beteken het dat daar binne afsienbare tyd afgestudeerdes van die Opleiding beskikbaar sou wees nie. In 1917 was daar wel twee "eie" predikante naamlik ds JJ Prinsloo en ds JJ Kühn, die kwekelinge van prof PJ Muller wat albei in 1909 diens aanvaar het. Dit sou egter tot 1921 duur voordat ds PJ Venter, die eerste "produk" van die eie Opleiding in diens kon tree. Na Van Broekhuizen het ds AJ Barger (Ndl), ds DF Erasmus (NG Kerk) ds GE Alers (Ndl) en ds WJ Poën (NG Kerk) nog vanuit ander kerke na ons as predikante oorgekom

14. Notulen der Algemene Vergadering der Nederd Hervormde Kerk, 1917, bl 21. Daar stel ds LE Brandt, dan voorsitter van die Kommissie van die AKV: Wat betreft de beroeping van ds Barger: de Algemene Commissie had aanbevelingsbrieven van prof Obbink en student Engelbrecht en bovendien een brief van ds van Broekhuysen zelf, dat ds Barger graag tot kerk sou komen. En op die dokumenten heeft de Algemene Commissie zijn beroeping toegestaan ... Ds Ruysch van Dugteren was door hem zonder beroep ingevoerd, dat is zo, maar waarom? Omdat hij wist, dat sommige gemeenten behoefte hadden aan predikanten. Hij heeft hem bewogen over te komen en kennis te maken en Pretoria heeft hem beroepen ... In 1914 met de beroeping van dr Greyvenstein, heeft de kerkeraad wel eerst toestemming gevraagd. Dus hij wist de weg...

Tydens die vergadering van die Kommissie van die AKV op 28 Junie 1917 het ds LE Brandt daar gestel: De regel is dat een predikant zich moet aanmelden voor hy beroepbaar kan gesteld worden.

Dit wil voorkom asof die Kommissie die reg wou voorbehou om predikante uit ánder kerke aan die gemeentes "beskikbaar" te stel en nie wou toelaat dat ' $n$ kerkraad self predikante uit ander kerke beroep nie.

15. Vergelyk ds Murray se opmerking in Notulen der AKV 1917, bl 28.

16. Notulen der Commissie der AKV,18 April 1917.

17. Notulen der Algemene Vergadering der NHK, 1917, bl 15.

18. Van Broekhuizen het in sy skrywe aan die kerkraad die volgende op 28 Mei 1917 gestel: $\mathrm{Na}$ ons onderhoud van gisteren met $\mathrm{u}$ en de andere Comm. leden, wensch ik u de volgende mee te deelen:

(1) Dat ik altyd sympathiek ben geweest tegenover de Herv Kerk. Dit heb ik getoond in al myn doen en laten, door myn optreden toen ik nog predikant van de Vereenigde Kerk te Pretoria was.

(2) Dat ik gedoopt ben in de Herv Kerk, Ryssen, Nederland.

(3) Dat ik myn bewys van lidmaatschap heb ingediend by de Herv gemeente, Pretoria.

(4) Dat ik geheel en al gewillig ben te voldoen aan Art 24(c) van de Wetten en Bepalingen voor de Ned Herv Kerk van $z$ Afr.

19. Dit wil voorkom asof $d s$ Brandt se versoeningsvoorstel slegs 'n persoonlike mening was en nie die opvatting van die Kommissie weergegee het nie. Terwyl hy voorsitter van die Kommissie was, het die kerkraad egter aangeneem dat sy voorstel 'n amptelike menir.g was. Merkwaardig genoeg het ds Brandt hierdie versoeningsvoorstel na die besprekings van 25 Mei nie in die vergadering van die Kommissie gestel of verdedig nie. Die Kerkraad het in sy vergadering van 6 Julie 1917 dié saak as volg opgeteken: ... na een diskussie van drie uren, als resultaat der bespreking, door een Lid van de kerkeraad aan de Voorzitter, Ds Brandt is gevraagd: of nu moet worden verstaan, dat, wanneer Ds van Broekhuizen gewillig is te voldoen aan de Art, 2, 24c van de Wetten en Bepalingen, de Alg Komm geen verdere bezwaren heeft, daarop door Ds Brandt "Ja" is geantwoord en geen der andere leden van de $\mathrm{Alg}$ Komm daartegen iets in het midden heeft gebracht.

20. Oudl ADW Wolmarans het dan ook op die vergadering van die Kommissie van die AKV voorgestel: ... gezien hebbende dat ds van Broekhuizen zyne attestatie heeft ingediend welke ook is afgekondigd en zich bereid verklaard heeft zich te onderwerpen aan een examen bedoeld in art 24 van de Kerkwet; 
verder overtuigd zijnde dat wij op dit oogenblik nog verkeeren in een zekere mate van predikantennood en door onze kerk zelf niet binnen een al te korten tijd zal kunnen worden voorzien in het bestaande behoefte;

lettende op de verklaring dat de gemeente Pretoria op dit oogenblik zich in een toestand van herderloosheid bevindt en dien ten gevolge ook geestelyk en stoffelyk noodwendig moet achteruitgaan, besluit om van haar bezwaar tegen het beroep van Ds van Broekhuizen af te zien en hierby de genoemde goedkeuring aan den kerkeraad van Pretoria te verlenen.

21. Die Formulier om die Dienaars van die Goddelike Woord te bevestig stel tog duidelik: Aangesien niemand voor ons verskyn het wat iets wettigs teen sy persoon voorgebring het nie, sal ons nou in die Naam van die Here tot sy bevestiging oorgaan.

Dié sinsnede kon in ieder geval nie by Van Broekhuizen se bevestiging gelees word nie.

Die Kommissie van die AKV het dan ook op 31 Julie 1917 'n skerp brief van protes teen die voorgenome bevestiging aan die kerkraad gestuur. Nadat al die artikels van die Wetten en Bepalingen wat oortree sou word met dié bevestiging opgesom is, het die brief ook gestel: Ondergeteekenden (ds LE Brandt en ds J van Belkum) meenen, dat het hun plicht is, $u$ te wijzen op de onwettigheid van uwe handelwijze en van die van den beroepen Leeraar met het oog op de gevaren daaraan verbonden voor de Kerk in het algemeen en de Gemeente van Pretoria in het bijzonder, waarvan de verantwoordelijkheid dan ook geheel op u rust.

Die Kerkraad was nou so verhard in sy standpunt dat dié brief verwerp is en die Kerkraad op sy vergadering van 4 Augustus 1917 besluit het: ... en Ds van Broekhuizen dus door de eis van de Algemene Commissie op verzoek van de Kerkeraad van zijn eigen kerk heeft losgemaakt, mag de Kerkeraad, wil hij zichzelf eren, nu niets anders doen kan dan ZW Eerw Ds van Broekhuizen in bescherming te nemen tegenover het gedrag van de Algemene Commissie.

22. Ons Vaderland, 7 Aug. 1917. Aanhalings uit Intree-preek van ds Herman D van Broekhuizen, Pretoria 1917, bl 3-4.

23. Art 23 het bepaal: De Comm der AKV zal waken voor de uitvoering der kerkelijke wetten en besluiten; zal oordelen en beslissen omtrent de beteekenis, de bedoeling en toepassing van de artikelen der wet in voorkomende gevallen; ...

24. Notulen der Algemene Vergadering der NHK, 1917, bl 25.

25. Notulen der Algemene Vergadering der NHK, 1917, bl 29.

26. Notulen der Algemene Vergadering der NHK, 1917, bl 19.

27. BM Schoeman, Parlementêre Verkiesing in Suid-Afrika 1910-1976, Pretoria 1977, bl 155.

28. Ons Vaderland, 12 Februarie 1924.

29. In 'n toespraak, Onze Kracht, wat hy op 23 September 1911 uitgespreek het, het Van Broekhuizen al gestel: De reuzen van het verleden, wat roepen zij ons toe? Houdt wat gij hebt! Dit was het geheim van hun heldenmoed, van hun grootheid - hun Godsdienst, hun geloof ... Daarom komt vandaag tot ons, als een machtige stem uit het verleden: de stem der vaderen, de stem der geschiedenis en boven alles de stem van Gods Woord. Gerechtigheid verhoogd een volk. Niet de wijsheid der philosofie, niet de diplomatie der politici, maar wel oprechte godsvrucht. Politiek en diplomatie zijn goed en nuttig, maar het ééne nodige is: Gerechtigheid, dwz. Godsvrucht ...

Want ware Godsvrucht en ware patriottisme zijn onafscheidelijk aan elkeen verbonden ... Gods zij dank er wordt nog blakende en brandende vaderlandsliefde gevonden. Maar, 0 , ik ben zoo bevreesd dat die liefde en ijver misplaatst zijn omdat zoo velen van hen het heil van het vaderland zoeken buiten Gods Woord ... Dat is gedoemd! Neen, alleen ware, oprechte godsvrucht is het behoudt, het leven, de uitbreiding van ons volk. Die is te vinden door Jezus Christus, bij God!

30. Ons Vaderland, 26 Oktober 1925.

Met sy bedanking as predikant het ds W Poën die konsulent, Van Broekhuizen hoë lof toegeswaai. Op 'n kerkraadsvergadering, waar Van Broekhuizen sy ontslag gekry het, notuleer die skriba (Kerkraadsvergadering 1.10.1925): Verder bedank ds Poën dr van Broekhuizen vir die werk ook deur hom gedoen in Noordelike 
Transvaal waar hy alles in so ' $n$ wonderbaarlike manier in orde gebreng het en die werk daar so alles in orde was dat hy feitlik die Noordelike Transvaal gered het vir die Hervormde Kerk. Ook op die Ringsvergaderinge waar hy vir jare voorsitter was en alles met veel beleid gelei het. 